\title{
Effect of Biofertilizers on Yield and Yield Components of Wheat (Triticum aestivum. L) Under Iraqi Conditions
}

\author{
Hadwan Hamid Ali ${ }^{1}$, Francis Araha Janno $^{2}$, Rafal Esmael Majed ${ }^{1}$, Muntaser Mansor Hamza ${ }^{1}$ \\ ${ }^{1}$ Directorate of Plant Protection, Ministry of Agriculture, Baghdad, Irap \\ ${ }^{2}$ Directorate of Agr-Research, Ministry of Agriculture, Baghdad, Irap
}

Email address:

Amara_1013@yahoo.com(H. H. Ali), francisjanoo@yahoo.com (F.A. Janno), Rafal_vip06@yahoo.com(R. E. Majed),

Muntaser077@gmail.com (M. M. Hamza)

\section{To cite this article:}

Hadwan, Hamid Ali, Francis Araha Janno, Rafal Esmael Majed, Muntaser Mansor Hamza. Effect of Biofertilizers on Yield and Yield Components of Wheat (Triticum aestivum. L) Under Iraqi Conditions. International Journal of Applied Agricultural Sciences.

Vol. 5, No. 2, 2019, pp. 45-49. doi: 10.11648/j.ijaas.20190502.13

Received: November 29, 2018; Accepted: February 1, 2019; Published: May 15, 2019

\begin{abstract}
The objective of the study was to evaluate the efficiency of biofertilizers in improving wheat yield, yield components, and nutrients balance in soil. Local and imported biofertilizers were applied in a field experiment at Erbil, Iraq for the season 2016-2017. The experimental design was Randomized Complete Block Design (RCBD) with four replicates. The experiment consisted of five treatments: $\mathrm{T} 1=$ Natrusoil (Commercial Biofertilizer) only, $\mathrm{T} 2=$ Natrusoil $+25 \%$ Chemical Fertilizers (CF), T3 = Local Biofertilizer B1 $+25 \% \mathrm{CF}$, T4 = Local Biofertilizers B2 $+25 \% \mathrm{CF}$, and T5 $=\mathrm{CF}$ as a Control (Recommended: Urea $=$ $260 \mathrm{~kg} / \mathrm{ha}, \mathrm{DAP}=180 \mathrm{~kg} / \mathrm{ha}$ ). Management practices in soil preparation and crop management followed the common and general procedures. Most test biofertilizers significantly increased yield of wheat grain or yield components. Maximum significant grain yield was obtained from biofertilizers treatments Natrusoil $+25 \% \mathrm{CF}$ (4.659) and B1+25\%CF (4.691) as compared with the Control $\left(3.987 \mathrm{~kg} \mathrm{ha}^{-1}\right)$. The increase in yield was in the range $17-18 \%$. The application of biofertilizer resulted in a positive effect on nutrients balance in the soil at the end of season regardless of type of biofertilizrs as indicated by the increase in levels of $\mathrm{NH}_{4}, \mathrm{NO}_{3}, \mathrm{P}$, and $\mathrm{K}$. Among the benefits of using bioferilizers is the reduction in cost. The reduction was $47 \%$ in using the imported Natrusoil $+25 \% \mathrm{CF}$ increased to $72 \%$ when using the Natrusoil alone.
\end{abstract}

Keywords: Biofertilizers, Bacteria, Fungi, Wheat, Yield, Mineral Fertilizers and Financial Cost

\section{Introduction}

Wheat is considered as one of the most important cereals crop. It has a special importance in Iraq because the local production is not sufficient to supply the annual demand thus, the country used to import wheat during the last sixty years according to almost all reports of central statistical belong to ministry of planning during the last decades. The best regions for wheat cultivation in terms of soil are areas with high amount of humus, enough aeration, and sufficient nutrients [1]. Researchers have estimated that $60 \%$ of land farms in the world lack nutrients availability for crops [2-3].

Agriculture practices in Iraq are heavily dependent on agrochemicals e.g, mineral fertilizers and pesticides. Irrational use of such agrochemicals would lead to the frequent soil pollution [4-5]. The use of chemical fertilizers and pesticides for promoting production level and protecting plants disturb ecological balance of the soil (Sharma 2002) [2]. Considerable quantities of heavy metals $\mathrm{Cd}, \mathrm{Pb}, \mathrm{Ni}$ and $\mathrm{Cr}$ have been reported in Iraqi soil with the use of DAP, NPK, rock phosphate and others [4-7]. In addition, organic matter in Iraqi soil is very low (nearly $1 \%$ ). Therefore, much attention has focused on biofertilizers to increase agricultural production and minimize pollution of environment [8-9].

The biological formulation obtained from commercial production of Trichoderma sp. for instance as biopesticide and promoter were developed at biological factories and successfully demonstrated at several wheat fields in many countries [10]. Use of biofertilizers is helpful in improving restoration of environment leveraging agriculture [11]. It was reported that Rhizobium sp. used as plant growth promoters for wheat, whereas Azospirilum sp. as nitrogen fixer [10]. On other hand, Bacillus megaterium act as phosphate solubilizer, 
while Trichoderma harizianum is considered as plant growth promoters as well as biopesticides. Biofertilizers are products containing living cells of different types of microorganisms when applied to seed, plant surface or soil, colonize the rhizosphere or the interior of the plant and promotes growth by covering nutritionally important elements (nitrogen and phosphorus) from unavailable to available forms [11]. This is occurred through biological process such as nitrogen fixation and solubilization of rocks and phosphate with the combination of fungi and bacteria [8-9, 12].

The Plant Growth Promoting Rhizobacteria (PGPR) promoted plant growth directly through the process of fixation of atmospheric nitrogen, solubilization of phosphorus, production of siderophorus that soloubilize and sequester iron, and production of hormones regulators. Some bacteria support plant growth indirectly by improving and/or eliminating the growth restricting conditions either via production of antagonistic substances or by inducing resistance against plant pathogens [12].

Improving soil fertility is one of the important strategies in increasing agricultural products through compensation application of chemical fertilizers by bio and organic fertilizers [13-14]. Combination of mineral and organic fertilizers can directly increase yield and quality parameters in comparison to mineral fertilizers applied alone and can cause environmentally improvements [8, 11, 15-16]. It is suggested to use a combination of organic and mineral fertilizers to improve grain quality that will lead to environment conservation achieve without a negative effect [17].

Several local contributions were achieved, out of them some were practically related to response of wheat to biofertilizers [18-19] who reported that biofertilizers alone or in combination significantly increased yield of wheat and improve soil characteristics.

The study was conducted to investigate the effect of both local and commercial biofertilizers in combination with mineral fertilizers on yield and yield components of wheat under climate conditions of northern Iraq. Also, reference has been made to local financial cost.

\section{Materials and Methods}

The experimental site is located in Erbil nearly $323.7 \mathrm{~km}$ North West Baghdad, Iraq with coordinates of $36.2 \mathrm{~N}$ and $44.0 \mathrm{E}$ and elevation of $390 \mathrm{~m}$. During the wheat growing season $(2016-2017)$, the mean min temperature ranged from 3 to $17^{\circ} \mathrm{C}$ and mean max from 28 to $30^{\circ} \mathrm{C}$. The average precipitation was $540 \mathrm{~mm}$.

For characterization of soil, sampling was made at $0-30 \mathrm{~cm}$ depth. The soil samples were air-dried and grounded to pass $2 \mathrm{~mm}$ sieve. Physical and chemical characteristics of soil were determined using the general procedures described by Reference [20]. Particle size analysis was carried out using the hydrometer method. Chemical soil analysis was carried out as follows: $\mathrm{pH}$ and EC were determined with $\mathrm{pH}$-meter and electrical conductivity meter respectively using 1:1 soil: water suspension. Nitrogen as $\mathrm{NH}_{4}-\mathrm{N}$ was determined using micro-Kjeldahl and $\mathrm{NO}_{3}-\mathrm{N}$ using Bremner and Keeney (1965) method, organic matter content using Walkley-Black acid digestion method. Soluble and extractable $\mathrm{K}$ was determined using flame photometer. Colorimetric method was applied to determine P using spectrophotometer method.

Table 1. Chemical and physical characteristics of the soil before cultivation.

\begin{tabular}{lll}
\hline Character & Unit & Value \\
\hline Electrical conductivity (EC) & $\mathrm{dS} \mathrm{m}^{-1}$ & 1.2 \\
$\mathrm{pH}$ & --- & 7.3 \\
Organic Mater (OM) & $\%$ & 1.1 \\
$\mathrm{~N}^{-\mathrm{NH}_{4}}$ & & 30 \\
$\mathrm{~N}^{-\mathrm{NO}_{3}}$ & & 35 \\
$\mathrm{P}$ & $\mathrm{mg} \mathrm{kg}^{-1}$ & 12.6 \\
$\mathrm{~K}($ Soluble) & & 79 \\
$\mathrm{~K}($ Extractable) & & 203 \\
$\mathrm{Clay}$ & & 30.5 \\
Silt & $\%$ & 17.5 \\
Sand & & 52.5 \\
Textural Class & Sand Clay Loam \\
\hline
\end{tabular}

Wheat Barcelona cultivar was sowed on Dec. 12, 2016 at a rate of $120 \mathrm{~kg}$ seeds $\mathrm{ha}^{-1}$. Five treatments were applied (Details of the treatments are given in Table 2):

* Crop managements were conducted as recommended practices for wheat crop.

T1: Natrusoil (Commercial Biofertilizer) only,

T2: Natrusoil $+25 \%$ of the recommended dose of chemical fertilizers $(\mathrm{CF})$,

T3: Local Biofertilizer B1 $+25 \%$ of $\mathrm{CF}$,

T4: Local Biofertilizer B2 $+25 \%$ of $\mathrm{CF}$, and

T5: Control $(C F)\left(\right.$ Urea $\left.=260 \mathrm{~kg} \mathrm{ha}^{-1}, \mathrm{DAP}=180 \mathrm{~kg} \mathrm{ha}^{-1}\right)$.

The size of block was 2.5 ha replicated four times. Each block containing the five treatments with 0.5 ha for each treatment (experimental unit).

Table 2. Formulas of biofertilizer and chemical fertilizers.

\begin{tabular}{ll}
\hline Treatments & Description \\
& Natrusoil only, \\
& (Natrusoil is compatible mixture of humic acid $1.5 \%$ and \\
& some Bacillus species recorded up to $10 \times 10^{20}$ c.f.u. $/ \mathrm{mL}-$ \\
& it is vincula product. \\
& Bacteria 02\%, Bacillus subtillis, Bacillus magterium \\
& Bacillus polymyax, Bacillus licheniformis, Bacillus \\
& uniflagellatus \\
& Bacillus laterosporus, Bacillus chitinoporus). \\
& Natrusoil + 25\% Chemical Fertilizer \\
T2 & Local Formula B1+25\% Chemical Fertilizer. \\
& (Formula B1 contains Rhizobium cicceri + Asospirillium \\
T3 & baselines + Trichodermaharizium) \\
& Local Formula B2 + 25\% Chemical Fertilizer. \\
& (contains Rhizobium cicceri + Azospirillium basilenes + \\
T4 & Trichoderma harzianum + Bacillus megaterium) \\
& Control (The Recommended Chemical Fertilizer: Urea = \\
& 260 kg/ha and \\
T5 & DAP = 180 kg/ha).
\end{tabular}

* Vincula Industries, Inc. P.O. Box 2549, Haker Heights, TX 76548 USA, phone.760-900-9927. Email: subhi@vincula.com.

The local bacterial isolates were isolated and purified in the organic laboratories and grown on $1000 \mathrm{~mL}$ nutrient 
broth flasks and incubated at 28 oC in cooled shaking incubator for 2 days till attain uniform density 107- 108 $\mathrm{cfu} / \mathrm{mL}$ (Majed et.al 2017). The culture then carried on the solid sterilized carrier containing charcoal + peatmos and incubated at $28 \mathrm{oC}$ for $24-48 \mathrm{~h}$. Seed coating was the method used with the local bacterial isolates whereas spraying the field by diluted sample was used for Natrusoil. For the later imported biofertilizer, 1.0 L of Natrusoil was diluted in $400 \mathrm{~L}$ of clean water enough for 1.0 ha area and sprayed evenly on land just before sowing and plowing.

Natrusoil is a compatible commercial liquid mixture of humic acid $1.5 \%$ and of some Bacillus spp recorded up to $(10 * 1020$ c.f.u/mL). The microorganisms of Natrusoil are several species of bacteria (Table 1), considered as source of B. subtilis as biopesticides, B. megaterium as phosphate solubilizes, Bacillus polymyxa as $\mathrm{N} 2$ fixer, and $\mathrm{B}$. licheniformis secreted many enzymes and antibiotics. Similarly, B. uniflagellates are considered as source of biopesticides, B. laterosporus helps in balancing of normal flora and as source of pesticides while B. chitinoporus works on hydrolysis of compound. Information and the product
"Natrusoil" are from Vincula Industries, Inc., USA.

Feasibility study was performed to compare the financial cost of mineral fertilizers and biofertilizers alone or in combination with the mineral fertilizer.

\section{Results}

\subsection{Effect of Biofertilizer on Wheat Yield, Yield Components, and Soil Nutrients Status}

Most test biofertilizers significantly increased yield of wheat grain or yield components (Table 3). Natrusoil $+25 \% \mathrm{CF}$ and $\mathrm{B} 1+25 \% \mathrm{CF}$ increased yield by $17-$ $18 \%$ over the control. Similarly, number of spikes $/ \mathrm{m}^{2}$ for Natrusoil, B1+25\%CF, and $\mathrm{B} 2+25 \% \mathrm{CF}$ increased by 6 to $27 \%$ over the control. Weight of 1000 kernel for Natrusoil $+25 \% \mathrm{CF}, \mathrm{B} 1+25 \% \mathrm{CF}$, and $\mathrm{B} 2+25 \% \mathrm{CF}$ increased by $18-25 \%$ over the control. The number of spikes and weight of $1000 \mathrm{kernel}$ are the main factors responsible for the increase in yield. On the other hand, no significant differences were found for the weight of spikes.

Table 3. Biofertilizers effect on wheat yield and its components during the season 2016-2017 in Erbil province, Iraq.

\begin{tabular}{|c|c|c|c|c|}
\hline Treatment & No. of spikes $\mathrm{m}^{-2}$ & Grain spike $^{-1}$ (g) & Weight 1000 grain gm) & Yield (ton ha' ${ }^{-1}$ ) \\
\hline T1 (Natrusoil) & $413.3^{*}$ & 34.33 & 36.67 & 4.427 \\
\hline $\mathrm{T} 2$ (Natrusoil $+25 \% \mathrm{CF}^{+}$) & 384.1 & 40.53 & $42.20 *$ & $4.659 *$ \\
\hline $\mathrm{T} 3(\mathrm{~B} 1+25 \% \mathrm{CF})$ & $426.7^{*}$ & 34.00 & $41.13 *$ & $4.691 *$ \\
\hline $\mathrm{T} 4(\mathrm{~B} 2+25 \% \mathrm{CF})$ & $436.7 *$ & 34.17 & $39.80 *$ & 4.578 \\
\hline T5 (Control, $100 \% \mathrm{CF}$ ) & 343.7 & 39.60 & 33.70 & 3.987 \\
\hline $\operatorname{LSD}_{0.05}$ & 55.23 & 3.697 & 4.347 & 0.615 \\
\hline
\end{tabular}

${ }^{+} \mathrm{CF}=$ Chemical Fertilizer.

* significant at the 0.05 level of probability.

It is clearly evident that the levels of nutrients in the soil after harvest have been increased with the application of chemical fertilizer or biofertilizers regardless of type of biofertilizrs (Table 4). The increase in nutrients of biofertilizer treatments was in the ranged of $33-77 \%, 20-80 \%, 56-74 \%, 11-39 \%$, and $3-25 \%$ for $\mathrm{NH}_{4}, \mathrm{NO}_{3}, \mathrm{P}, \mathrm{K}_{\text {sol }}$, and $\mathrm{K}_{\text {ext }}$, respectively.

Table 4. Effect of application of biofertilizers on nutrients status in the soil after harvest of wheat crop. (Data for nutrients in the soil before cultivation are included for comparison).

\begin{tabular}{|c|c|c|c|c|c|c|}
\hline \multirow{2}{*}{\multicolumn{2}{|c|}{ Soil Sample }} & $\mathbf{N H}_{4}$ & $\mathrm{NO}_{3}$ & $\mathbf{P}$ & K (Sol) & K (Ext) \\
\hline & & \multicolumn{5}{|c|}{$\mathrm{mg} \mathrm{kg}^{-1}$} \\
\hline \multicolumn{2}{|c|}{ Before cultivation } & 30 & 35 & 12.6 & 79 & 203 \\
\hline \multirow{4}{*}{ After Harvest } & T1 (Natrosoil) & 53 & 42 & 19.9 & 88 & 221 \\
\hline & $\mathrm{T} 2\left(\right.$ Natrsoil $\left.+25 \% \mathrm{CF}^{+}\right)$ & 40 & 43 & 21.5 & 72 & 254 \\
\hline & $\mathrm{T} 3(\mathrm{~B} 1+25 \% \mathrm{CF})$ & 51 & 63 & 19.6 & 110 & 243 \\
\hline & $\mathrm{T} 4(\mathrm{~B} 2+25 \% \mathrm{CF})$ & 45 & 59 & 5.0 & 98 & 210 \\
\hline
\end{tabular}

${ }^{+} \mathrm{CF}=$ Chemical Fertilizer.

\subsection{Economic Evaluation}

Financial evaluation of using the imported biofertilizer (Natrosoil) alone or in combination with $25 \%$ of chemical fertilizer (T1 and T2) as compared with using of chemical fertilizer T5 (Control) is given in Table 5. The evaluation is based on the subsided prices of the chemical fertilizer, but not on prices in local market. The latter is much higher than the subsided price. The reduction in cost per one hectare area when using Natrusoil $+25 \%$ CF was 126,000 ID (ID, Iraqi Dinar $=1,200$ US Dollar). Further, the reduction in cost reached 193,000 ID when using the Natrusoil alone. In percent, the reduction in cost was $47 \%$ and $72 \%$ for Natrasoil $+25 \% \mathrm{CF}$ and Natrusoil, respectively. Application of biofertilizers resulted in decreasing agricultural cost worldwide which supported the existing contribution (Abd El-Gawad and El-Sayed 2009, Sharma et. al 2012; Yasin et. al 2012). 
Table 5. Financial cost of fertilizers under study per hectare on wheat fields in Iraq.

\begin{tabular}{lllc}
\hline Fertilizer & Dose $/$ ha & Cost /kg or L (ID $)$ & Total Cost/ha (ID) \\
\hline Urea & $260 \mathrm{~kg}$ & 500 & 130,000 \\
DAP & $180 \mathrm{~kg}$ & 770 & 138,600 \\
Both Urea + DAP $\left(\mathrm{CF}^{++}\right)$ & $180 \mathrm{~kg}+260 \mathrm{~kg}$ & 75,000 & 268,600 \\
Natrusoil & $1 \mathrm{liter}$ & 500 & 75,000 \\
$25 \%$ Urea & $65 \mathrm{~kg}$ & 770 & 32,500 \\
$25 \%$ DAP & $45 \mathrm{~kg}$ & 34,650 \\
Natrusoil + $25 \% \mathrm{CF}$ & $1 \mathrm{~L}+65 \mathrm{~kg}+45 \mathrm{~kg}$ & 142,150 \\
Reduction in cost when using Natrusoil alone (T1) & $268,600-75,000=193,600$ & \\
Reduction in cost when using Natrusoil + $0.25 \% \mathrm{CF}(\mathrm{T} 2)$ & $268,600-142,000=126,600$ & \\
\hline
\end{tabular}

ID = Iraqi Dinar (One US. Dollar $=1200$ ID)

${ }^{++} \mathrm{CF}=$ Chemical Fertilizer

\section{Discussion}

Pollution in Iraqi soils has been indicated in several reports due to the application of DAP, NPK, and rock phosphate. Such application resulted in buildup of $\mathrm{Cd}, \mathrm{Pb}, \mathrm{Ni}, \mathrm{Cr}$ in soil and also in contamination of wheat by $\mathrm{Cd}$ and $\mathrm{Pb}$ [7]. The levels of $\mathrm{N}$ in the forms of $\mathrm{NO}_{3}$ and $\mathrm{NH}_{4}, \mathrm{P}$, and $\mathrm{K}$ increased in the soil after harvesting due to the application of biofertilizer as well as the chemical fertilizer. The lowest value of $\mathrm{P}$ was noticed in the biofertilizer treatments (T1 T4) demonstrated that Plant Growth Promoting Rhizobacteria (PGPR) dissolved the mineral phosphorus and increased its available for crop uptake. This result is supported by Ref. [11]. Results presented in Table 1 indicated that biofertilizers have positive effect on plant growth and play a great role in making the nutrients $\mathrm{N}, \mathrm{P}$ and $\mathrm{K}$ available for plant uptake. In the same line Ref. Similar results on enhancing the availability of nutrients in soil with application of biofertilizer are achieved [21].

Plant growth and yield parameters indicated that inoculation with biofertilizers B1 and B2 as solid or Natrusoil as liquid fertilizers individually or in combination gave an enhancement effect on both plant growth and yield (Table 3 ). These results are agreed and supported by several researchers [17, 22-24]. They indicated that in some species and strains of Azotobacter, Azospirillium, Bacillus, Pseudomonas and some fungal species, Trichoderma and others have significant effect on number of spikes, seed weight, and number of seeds as well as yield.

The superiority of biofertilizers application when accompanied with reasonable amounts of mineral fertilizer can be due to $\mathrm{N}$ fixation, $\mathrm{P}$ solubility, supplying humic acid, growth promoting, and diseases resistance. On the other hand, chemical fertilizer alone can be imbalanced and insufficient.

\section{Conclusions}

Response of Wheat to biofertilizers alone or in combination with $25 \%$ of recommended dose of mineral fertilizers was positive. The biofertilizer increased yield and yield components of wheat, improve soil nutrients balance, and minimize environmental pollution. Among the benefits of using bioferilizers was the reduction in cost as compared with the use of full dose of mineral fertilizer.

\section{References}

[1] HisniKovasky, L. and E. Kunzova (2014) Effect of mineral and organic fertilizers on yield and Technological parameters of Winter wheat (Triticum aestivum L) on Illimerized Luvisol. Polish Journal of Agronomy 17: 18-24.

[2] Sharma, A. K. (2002) Biofertilizers for sustainable agriculture, Agro-Bios. pp300.

[3] Heidaryan, J. and A. Feilinezhad (2015) On the effect of biofertilizers on the yield and yield components of wheat (Triticum aestivum L) under Eyvan climate conditions. Biological forum - An international Journal 7(1): 581-585.

[4] Salah, E. A. M., K. H. Yassin and S. Abd-AlSalaam (2015) Level, distribution and pollution assessment of heavy metals in urban community garden soils in Baghdad city, Iraq International Journal scientific and engineering Research, 6 (10): 1646-1652c.

[5] Tawfiq L. N. M. and F. F. Ghazi (2017) Heavy metals pollution in soil and its influence in south of Iraq. International Journal of Discrete Mathematics, 2(3): 59-63.

[6] Al-Maiahy, R. S. B. (2012) Phosphatic fertilizers and organic manures content of some heavy metals and their effects on soil and wheat plant pollution (Triticum aestivum L.). M. Sc. Thesis. College of Agriculture, University of Basrah.

[7] Manii, J. K. (2014) Using GIS to study the probability pollution of surface soil in Babylon province, Iraq. Journal of applied Geology and Geophysics (10SR-JAG) 2(1): 14-18.

[8] Abou El-Yazeid, A., H. E. Abou-Aly, M. A. Mady and S. A. M. Moussa (2007) Enhancing growth productivity and quality of squash plants using phosphate dissolving microorganisms (bio phos-phor) combined with boron foliar spray. Res. J. Agric. Biol. Sci., 3(4): 274-286.

[9] Mohammadi K. and Y. Sohrabi (2012) Bacterial biofertilizers for sustainable crop production. ARPN Journal of Agricultural and Biological Science 7(5): 307-3016.

[10] Sharma, P., A. N. Patel, M. K. Saini and S. Deep (2012) Field demonstration of Trichoderma harizianum as plant growth promoter in wheat (Triticum asetivum L) Journal of agricultural science, 4(8): 56-73. 
[11] Yasin, M., K. Ahmad, W. Mussarat and A. Tanveer (2012) Bio-fertilizers, substitution of synthetic fertilizers in cereals for leveraging agriculture. Crop and Environment 3(1-2): 6266.

[12] Pramod, W. R. (2017) Rhizobacteria in sustainable Agriculture development. Technological Advancement for Sustainable Agriculture and Rural Development (TASARD-India), 11.

[13] Abd El-Gawad, A. M. and Z. T. El-Sayed (2009) Evaluation the response of wheat to Bio-organic Agriculture under Siwa Oasis conditions. Indian J. Agric. Asci., 49: 34 - 43.

[14] Castagno, L. N., M. J. Estrella, A. Grassano, and O. A. Ruiz (2008) Biochemical and molecular characterization of phosphate solubilizing bacteria and evaluation of its efficiency promoting the growth of lotus tenuis. Lotus Newsletter, 38 (2): 53-56.

[15] Ahmed, M., A. Hussein, M. F. Zakhtar, M. Zafar-U-Hye, Z. Iqbal, T. Naz, M. M. Iqbal (2017) Effectiveness of multi-strain biofertilizers in combination with organic sources for improving the productivity of Chickpea in drought ecology. Asia Journal Agriculture and biology 5(4): 228-237.

[16] HisniKovasky, L. and E. Kunzova (2014) Effect of mineral and organic fertilizers on yield and Technological parameters of winter wheat (Triticum aestivum L) on Illimerized Luvisol. Polish Journal of Agronomy 17: 18-24.

[17] Ali, N. and T. Khandan (2013) Response of wheat to mineral nitrogen fertilizer and biofertilizer (Azotobacter sp. and Azospirillum sp.) inoculation under different levels of weed interference. Ekologija, 59(2): 85-94.

[18] Abed, Y. M., H. A. Abedelrathe and H. A. Hadwan (2016) Effectiveness of biofertilizers produced from Pseudomonas
Putida and Pseudomonas flourescens on soil characteristics and wheat yield (Triticum asetivum L) and yield component. Iraqi Agriculture sciences Journal 47: 1412-1404.

[19] Majed, R. E., H. A. Hadwan, H. A. Abed, M. M. Hamza, O. F. Hasan and E. H. Ali (2017) Estimate different bioagent as a biofertilizers with two levels from chemical fertilizers on wheat crop improvement. Iraqi Journal Science 58(4B): 20352040 .

[20] Page, A. L., R. H. Miller and D. R. Keeney (1982) Methods of soil analysis. Part2. Chemical and microbiological properties. $2^{\text {nd }}$ ed. American Society Agronomy Inc., Soil Science Amer. Inc. Madison Wisconsin, USA.

[21] Belimov, A. A., P. A. Kojemiakov and C. V. Chuvarliyeve (1995) Interaction between barley and mixed cultures of nitrogen fixing and phosphate solubilizing bacteria. Plant and Soil, 173: 29-37.

[22] Heidaryan, J. and A. Feilinezhad (2015) On the effect of biofertilizers on the yield and yield components of wheat (Triticum aestivum L) under Eyvan climate conditions. Biological forum - An international Journal 7: 581-585.

[23] Mozafari, A., J. Daneshian, D. Habibi, A. H. Shirani Rad, F. Asgharzad (2012) The effect of growth promoting bacteria on yield and components of bread wheat in normal and soil tension conditions. $12^{\text {th }}$ Congress of Agricultural Sciences and Plant Modification of Iran Islamic Azad University of Karaj. 14-16.

[24] Verma, M., S. Sharma, R. Prasad (2011) Liquid biofertilizer: Advantage over carrier-based biofertilizer for sustainable crop production. Newsletter International Society Environment Botany 17(2). 